\title{
Safeguarding the Dynamic Legal Position of Children: A Matter of Age Limits?
}

\author{
Reflections on the Fundamental Principles and Practical Application of Age Limits in Light of \\ International Children's Rights Law
}

Stephanie Rap, Eva Schmidt \& Ton Liefaard*

\begin{abstract}
In this article a critical reflection upon age limits applied in the law is provided, in light of the tension that exists in international children's rights law between the protection of children and the recognition of their evolving autonomy. The main research question that will be addressed is to what extent the use of (certain) age limits is justified under international children's rights law. The complexity of applying open norms and theoretically underdeveloped concepts as laid down in the UN Convention on the Rights of the Child, related to the development and evolving capacities of children as rights holders, will be demonstrated. The UN Committee on the Rights of the Child struggles to provide comprehensive guidance to states regarding the manner in which the dynamic legal position of children should be applied in practice. The inconsistent application of age limits that govern the involvement of children in judicial procedures provides states leeway in granting children autonomy, potentially leading to the establishment of age limits based on inappropriate - practically, politically or ideologically motivated - grounds.
\end{abstract}

Keywords: age limits, dynamic legal position, children's rights, maturity, evolving capacities

\section{Introduction}

The United Nations Convention on the Rights of the Child (CRC) departs from the presumptions that children are independent rights holders and that, because of their development and particular dependency and vulnerability, they require specific rights assuring treatment with humanity and respect for human dignity and in a manner that takes into account their age and maturity. ${ }^{1}$ Several scholars have noted the tension within the

Stephanie Rap is assistant professor in children's rights at the Department of Child Law, Leiden Law School, the Netherlands. Eva Schmidt is PhD candidate at the Department of Child Law, Leiden Law School, the Netherlands. Ton Liefaard is Vice-Dean of Leiden Law School and holds the UNICEF Chair in Children's Rights at Leiden University, Leiden Law School, the Netherlands.

1. CRC, preamble; J. Sloth-Nielsen, 'Ratification of the Convention on the Rights of the Child: Some implications for South African Law', 11 South
CRC between protecting children on the one hand and on the other hand recognising children's evolving autonomy, which is, among others, reflected in the right to participate in diverse settings and decisions affecting them. ${ }^{2}$ The adoption of the CRC and the subsequent international and regional developments in international children's rights law have resulted in a comprehensive and multi-layered legal framework, under which children are defined as persons under the age of eighteen (see Art. 1 CRC) and are entitled to rights that safeguard their protection (against violence, exploitation and unlawful interference with private life, integrity and liberty), access to quality services and provisions (e.g. education, health care, social security, adequate standard of living, leisure and play) and participation. ${ }^{3}$

The inherent tension between protection and evolving autonomy becomes apparent when taking a closer look at the guidance that is given to CRC states parties regarding the implementation of certain rights in different contexts. The CRC deliberately enshrines norms and principles that are open and vague, in order to accommodate differences between states parties and to facilitate adaptation to different (legal) contexts. ${ }^{4}$ The principle of the best interests of the child (Art. 3(1) CRC) - one of the assumed guiding principles of the CRC, acknowledging its relevance for the interpretation and implementation of all other rights ${ }^{5}-$ is an example

African Journal on Human Rights 401 (1995); N. Cantwell, 'The Origins, Development and Significance of the United Nations Convention on the Rights of the Child', in S. Detrick (ed.), The United Nations Convention on the Rights of the Child. A Guide to the "Travaux préparatoires" (1992) 19.

2. N. Peleg, 'Illusion of Inclusion: Challenging Universalistic Conceptions in International Children's Rights Law', 24 Australian Journal of Human Rights 326, at 328-329 (2018); S. Varadan, 'The Principle of Evolving Capacities under the UN Convention on the Rights of the Child', 27 The International Journal of Children's Rights 306, at 322 (2019); G. Lansdown, The Evolving Capacities of the Child (2005), at 5.

3. U. Kilkelly and T. Liefaard, 'International Children's Rights: Reflections on a Complex, Dynamic, and Relatively Young Area of Law', in U. Kilkelly and T. Liefaard (eds.), International Human Rights of Children (2019) 617; K. Arts, 'Twenty-Five Years of the United Nations Convention on the Rights of the Child: Achievements and Challenges', 61 Netherlands International Law Review 267 (2014).

4. T. Liefaard, Deprivation of Liberty of Children in Light of International Human Rights Law and Standards (2008).

5. UN Committee on the Rights of the Child, General Comment No. 14 (2013) on the Right of the Child to Have His or Her Best Interests 
of such a vague and open norm, which is flexible but difficult to interpret and implement in practice at the same time. ${ }^{6}$ Also, the concepts of giving due weight to the views of the child in accordance with his or her age and maturity (Art. 12(1) CRC) and the evolving capacities of the child (Art. 5 CRC) are subject to diverse interpretations and are criticised for giving little guidance to states and professionals in practice. ${ }^{7}$ Tobin signals the lack of consensus on the meaning of particular children's rights and on the balance between protection and autonomy that needs to be established. ${ }^{8}$ Hollingsworth explains that the law should aim to provide the child with capacities for developing full autonomy and into a fully autonomous rights holder. ${ }^{9}$ In light of this, children are seen as human beings in development, which distinguishes them from adults and merits their special treatment by the law. It is important to note that the CRC itself lacks thorough theoretical foundation ${ }^{10}$ and that, as will be discussed below, the guidance provided by the UN Committee on the Rights of the Child (CRC Committee) is not always clear or consistent. However, it is evident that under international children's rights law, children are entitled to a dynamic legal position that develops along with their age and increasing maturity and that this particular position is often expressed in domestic law through the imposition of different age limits. The dynamic legal position and the corresponding fluid concepts are thus, in practice, combined with more static notions such as age limits.

Taken as a Primary Consideration (Art. 3, para. 1) (CRC/C/GC/14) (2013), para. 1

6. See for instance M. Freeman, A Commentary on the United Nations Convention on the Rights of the Child, Article 3: The Best Interests of the Child (2007).

7. See for example A. Daly, “No Weight for "Due Weight"? A Children's Autonomy Principle in Best Interest Proceedings', 26 The International Journal of Children's Rights 61 (2018); K. Hanson, 'Children's Participation and Agency When They Don't "Do the Right Thing"', 23 Childhood 471 (2016); E.K.M. Tisdall, 'Children and Young People's Participation: A Critical Consideration of Article 12', in W. Vandenhole, E. Desmet, D. Reynaert and S. Lembrechts (eds.), Routledge International Handbook of Children's Rights Studies (2015) 185; T. Liefaard, 'Juvenile Justice from an International Children's Rights Perspective', in W. Vandenhole, E. Desmet, D. Reynaert and S. Lembrechts (eds.), Routledge International Handbook of Children's Rights Studies (2015) 234.

8. J. Tobin, 'Understanding a Human Rights Based Approach to Matters Involving Children: Conceptual Foundations and Strategic Considerations', in A. Invernizzi and J. Williams (eds.), The Human Rights of Children: From Visions to Implementation (2011) 61, at 78; see also K. Hanson, 'Schools of Thought in Children's Rights', in M. Liebel, K. Hanson, I. Saadi and W. Vandenhole (eds.), Children's Rights from Below: Cross-Cultural Perspectives (2012) 63, at 70.

9. K. Hollingsworth, 'Theorising Children's Rights in Youth Justice: The Significance of Autonomy and Foundational Rights', 76 The Modern Law Review 1046, at 1060 (2013).

10. J. Tobin, 'Seeking to Persuade: A Constructive Approach to Human Rights Treaty Interpretation', 23 Harvard Human Rights Journal 1 (2010); Tobin (2011), above n. 8; M. Freeman, 'Why It Remains Important to Take Children's Rights Seriously', 15 The International Journal of Children's Rights 5, at 10 (2007); M. Freeman, 'Taking Children's Rights More Seriously', 6 International Journal of Law and the Family 52, at 59 (1992); J. Eekelaar, 'The Emergence of Children's Rights', 6 Oxford Journal of Legal Studies 161, at 170-171 (1986); Hanson, above n. 8; K. Hanson and N. Peleg, 'Waiting for Children's Rights Theory', 28 International Journal of Children's Rights 15 (2020).
This raises the question, To what extent is the use of (certain) age limits justified under international children's rights law?

This article provides a critical reflection upon age and age limits, in light of the tension between protecting children and recognising their evolving autonomy under international children's rights law. This article, first, reflects on the position of children and their evolving capacities within the CRC, as the key instrument of international children's rights law. Subsequently, the practical application of age limits is attended to by providing various case studies of how age limits are established by states parties in different legal contexts (namely, in juvenile justice, family law and care proceedings and migration law). The article concludes with some observations and reflections on the justification for the use of age limits under international children's rights law.

\section{The Perspective of the CRC on Children and Evolving Capacities}

The CRC can be characterised as a game changer as an instrument of international human rights law that recognises children as rights holders in the first place. ${ }^{11}$ The question as to what extent children have human rights and fundamental freedoms now seems superfluous. ${ }^{12}$ The CRC grants children additional or special rights that recognise their special status as being dependent, vulnerable or in need of special protection. ${ }^{13}$ Moreover, the CRC provides guidance regarding the enjoyment of rights. Article 5 CRC acknowledges, on the one hand, the child as rights holder who is entitled to enjoy his or her rights. At the same time, this core provision of the CRC recognises parents or others responsible for the child (including members of the extended family) as the ones who have the right, responsibility and duty to provide 'appropriate direction and guidance in the exercise by the child of the rights recognized in the CRC'. This direction and guidance must be given, however, in a manner that respects the child's 'evolving capacities'. With the introduction of the child's 'evolving capacities', Article 5 CRC reflects an attempt by the international legal community to capture the biological fact that children develop and mature over time and that this has implications for the role of the child's legal representative, in a provision of international law. ${ }^{14}$

11. See Freeman (2007), above n. 10; J. Tobin, 'Introduction: The Foundation for Children's Rights', in J. Tobin (ed.), The UN Convention on the Rights of the Child: A Commentary (2019) 2.

12. G. van Bueren, The International Law on the Rights of the Child (1995).

13. See e.g. Art. 19 CRC (protection against all forms of violence in a care setting) and Art. 31 CRC (right to leisure and play)

14. The CRC has, in a way, defined childhood as the period of time in which a person becomes 18 years of age, see Art. 1 CRC. This is not meant to serve other than as the age range to which the CRC is appli- 
The drafters of the CRC have chosen to include the concept of evolving capacities as the solution to the tension between the recognition of the need to protect the child and of the growing autonomy of the child. Consequently, the CRC can be seen as an instrument that recognises children as both in need of protection and as human beings with independent rights that they should be able to exercise in accordance with their development. ${ }^{15}$ On the basis of a comprehensive analysis of Article 5 CRC, Varadan concludes that in the three decades that have passed since the adoption of the CRC, the notion of evolving capacities has been given much broader meaning, in particular, by the CRC Committee, with - among others - more than eighty references in nineteen of the General Comments. ${ }^{16}$ As Varadan notes,

[I]t would appear that the Committee has introduced a broader principle of evolving capacities under the UNCRC that ... informs ... the interpretation and implementation of the Convention as a whole. ${ }^{17}$

Its meaning has thus been extended beyond the mere implications for the role of parents and others legally responsible for the child.

The notion of 'evolving capacities' can be seen as crucial to the conception of children and their rights under international law. ${ }^{18}$ Prior to the adoption of the CRC, the protection of family autonomy and the rights of parents with regard to the upbringing of their children had already been well established in various instruments of international law. ${ }^{19}$ The phrasing in Article 5 CRC, where it is stated that adults should provide appropriate direction and guidance in the exercise by the child of his or her rights, makes clear that this direction and guidance should be provided in a manner that respects the rights of the child. ${ }^{20}$ Varadan describes this as 'a somewhat radical departure from the traditional parent-child relationship, in which parents were the primary rightsholders and the child was a passive recipient of protection and care'. 21

The emphasis placed by the CRC Committee on the notion of evolving capacities has also had implications for the establishment of age limits and has, in fact, been used as a policy principle by the CRC Committee to encourage both the recognition of children's increasing autonomy and the establishment of (minimum) age laws in different areas. ${ }^{22}$ However, this has led to an inconsistent framework of (minimum) age limits that varies

cable, but it resonates with many domestic legal systems as well with other human rights instruments; T. Liefaard, 'Juveniles in Transition from Juvenile Justice to Adult Criminal Justice', in R. Loeber, M. Hoeve, N.W. Slot and P. van der Laan (eds.), Persisters and Desisters in Crime from Adolescence into Adulthood: Explanation, Prevention and Punishment (2012) 159.

15. Peleg, above n. 2, at 6; Varadan, above n. 2, at 5.

16. Varadan, above n. 2, at 308; see also Lansdown, above n. 2 .

17. Varadan, above n. 2, at 329.

18. Ibid., at 307 .

19. See for example ibid.; Lansdown, above n. 2, at 5 .

20. Varadan, above n. 2, at 319-320; Lansdown, above n. 2, at 5-6.

21. Ibid., at 307

22. Ibid., at 326-327 across legal fields and settings. The most fundamental age limit that can be found in the CRC, arguably, is in Article 1, which defines a child as 'every person under the age of 18', although exceptions can apply. For example, in General Comment No. $4,{ }^{23}$ the CRC Committee states,

States parties need to ensure that specific legal provisions are guaranteed under domestic law, including with regard to setting a minimum age for sexual consent, marriage and the possibility of medical treatment without parental consent. These minimum ages should be the same for boys and girls ... and closely reflect the recognition of the status of human beings under eighteen years of age as rights holders, in accordance with their evolving capacity, age and maturity. ${ }^{24}$

In General Comment No. 20, the CRC Committee states that minimum legal age limits should be introduced that recognise the right of adolescents to take increasing responsibility in decision making, for example, 'in respect of health services or treatment, consent to adoption, change of name or applications to family courts'. ${ }^{25}$ However, the CRC Committee also asks states to allow exceptions to those minimum age limits: 'In all cases, the right of any child below that minimum age and able to demonstrate sufficient understanding to be entitled to give or refuse consent should be recognized'. ${ }^{26}$ With respect to the right to be heard (Art. 12 CRC), the CRC Committee actually discourages states parties from introducing age limits - in law or in practice - because it would restrict the child's right to be heard. ${ }^{27}$ With regard to this right, the CRC Committee states that ' $[\mathrm{b}] \mathrm{y}$ requiring that due weight be given in accordance with age and maturity, Article 12 makes it clear that age alone cannot determine the significance of a child's views' ${ }^{28}$ Contrarily, in other areas, significantly stricter guidance is given with respect to establishing age limits. In General Comment No. 20, for example, the CRC Committee

reaffirms that the minimum age limit should be eighteen years for marriage, recruitment into the armed forces, involvement in hazardous or exploitative work and the purchase and consumption of alco-

23. The General Comments are authoritative, yet non-binding, recommendations made by the CRC Committee about how to implement certain provisions of the CRC.

24. UN Committee on the Rights of the Child, General Comment No. 4 Adolescent Health and Development in the Context of the Convention on the Rights of the Child (CRC/GC/2003/4) (2003), para. 5.

25. UN Committee on the Rights of the Child, General Comment No. 20 on the Implementation of the Rights of the Child During Adolescence (CRC/C/GC/20) (2016), para. 39.

26. UN Committee on the Rights of the Child (2016), above n. 25, para. 39.

27. UN Committee on the Rights of the Child, General Comment No. 12: The Right of the Child to be Heard (CRC/C/GC/12) (2009), paras. 21, 31.

28. UN Committee on the Rights of the Child (2009), above n. 27, para. 85. 
hol and tobacco, in view of the degree of associated risk and harm. ${ }^{29}$

Notwithstanding this seemingly absolute minimum age limit, in an earlier joint general recommendation with the UN Committee on the Elimination of Discrimination against Women, some leeway was provided to allow a lower minimum age limit for marriage:

When a marriage at an earlier age is allowed in exceptional circumstances, the absolute minimum age must not be below sixteen years, the grounds for obtaining permission must be legitimate and strictly defined by law and the marriage must be permitted only by a court of law upon the full, free and informed consent of the child or both children, who must appear in person before the court. ${ }^{30}$

Another example is that the CRC Committee advocates for fourteen as the minimum age of criminal responsibility (MACR), although it also commends states that have a higher minimum, such as fifteen or sixteen years of age. ${ }^{31}$ The CRC Committee has based this recommendation on scientific research on child and adolescent brain development. The explicit requirement to establish an MACR (Art. 40(3)(a) CRC) reflects the wish to protect children below a certain age from involvement in the justice system because of its potential harmful effects as well as the recognition of the responsibility of children for their behavior from a certain age onwards. ${ }^{32}$ Thus, Article 5 CRC, although originally meant to regulate the position of parents and other legal representatives in relation to the enjoyment of rights by the child, has been acknowledged as a key provision defining the legal status of children under international children's rights law. It reflects the child's development, evolving capacities and growing autonomy. It consequently gives guidance on how to strike a balance between protection on the one hand and participation and autonomy on the other hand. However, the approach of the CRC Committee with regard to capacities of children seems inconsistent, both substantively (see, for instance, the different options for the minimum age of marriage) and procedurally. As far as the latter is concerned, the CRC Committee renounces the use of age limits with regard to the right to be heard, since such limits can easily be used against children's participation (i.e. as a restriction). At the same time, the CRC Committee provides recommendations for specific age limits in order to pro-

29. UN Committee on the Rights of the Child (2016), above n. 25, para. 40.

30. UN Committee on the Elimination of Discrimination against Women and UN Committee on the Rights of the Child, Joint General Recommendation No. 31 of the Committee on the Elimination of Discrimination Against Women/General Comment No. 18 of the Committee on the Rights of the Child on Harmful Practices (CEDAW/C/GC/31CRC/C/GC/18) (2014), para. 55 sub f.

31. UN Committee on the Rights of the Child, General Comment No. 24 (2019), Children's Rights in the Child Justice System (CRC/C/GC/24) (2019), paras. 21-22.

32. See UN Committee on the Rights of the Child (2019), above n. 31, para 6(c). tect certain groups of children and prevent legal uncertainty and/or arbitrary treatment.

\section{Practical Perspectives on Age Limits}

Children's actual involvement in judicial proceedings and the legal capacity that is assigned to them is generally tied to age limits that are enshrined in domestic law. In the European Union (EU), children's capacity to take legal action or invoke judicial proceedings in their own right varies widely across, and within, member states. ${ }^{33}$ In half of the EU member states, children depend on legal representatives and/or guardians (usually parents) to bring a case before a court in civil and administrative proceedings. Also, minimum age limits are applied, ranging from twelve to sixteen years, to regulate the right of children to act in legal proceedings. Kennan and Kilkelly conclude that a selective and restrictive approach to the procedural rights of children has an impact on practice, because children are reliant on adults and their legal actions to vindicate their rights. ${ }^{34}$ The EU Fundamental Rights Agency (FRA) has concluded, in a recent overview of age limits in EU member states, that the right of children to be heard in legal proceedings varies remarkably among and within states as well, and across different areas of law (e.g. family, criminal and asylum and immigration law). ${ }^{35}$ Todres has drawn similar conclusions on the basis of his analysis of the concept of maturity and age limits as applied in the United States in different legal areas. The legal construct of maturity is applied inconsistently in the law, across and within certain issues related to children. ${ }^{36}$ For the purposes of this article, however, the analysis will be directed mostly to the European context.

In this section, case studies are presented of the various age limits that states apply in different areas of law, namely, in juvenile justice, family law and care proceedings and migration law. This section serves the purpose of providing examples of age limits that are set and the purposes these serve. It is not aimed at providing an exhaustive overview of all age thresholds within a certain area of law.

33. N. Kennan and U. Kilkelly, Children's Involvement in Criminal, Civil and Administrative Judicial Proceedings in the 28 Member States of the EU (2015), https://publications.europa.eu/en/publication-detail/-/ publication/c3cd307f-ff03-4010-b322-dcf7063403c5; E. Jansen, 'De eigen(aardige) procesbevoegdheid van de minderjarige', 30 Nederlands Juristenblad 2177 (2016).

34. Kennan and Kilkelly (2015), above n. 33.

35. FRA, Children's Rights and Justice. Minimum Age Requirements in the EU (2018), https://fra.europa.eu/en/publication/2018/minimum-agejustice.

36. J. Todres, 'Maturity', 48 Houston Law Review 1107 (2012). 


\subsection{Age Limits in Different Areas of Law}

\subsubsection{Fuvenile Fustice}

In the area of juvenile justice several age limits are of relevance, namely, the MACR, the age of criminal majority and, in some countries, specific age limits for deprivation of liberty or other sanctions. Moreover, states sometimes apply exceptions to the applicable age limits, for example, in case of serious crimes. ${ }^{37}$

Globally, the MACR differs substantially between countries, with some African and Asian countries and states within the United States that do not have a legal MACR and others that have an MACR starting as low as seven years and until eighteen years. ${ }^{38}$ In Europe, the overall average MACR is thirteen years, ranging from ten in England and Wales to eighteen years in, for example, Belgium. ${ }^{39}$ However, in some countries, children below the MACR may be prosecuted in case of a serious offence. For example, in Ireland, minors from the age of ten can be transferred to the adult court in the case of certain serious offences (s. 75 Children Act 2001). Arthur has characterised the English low MACR as taking 'a simplistic functionalist perspective' that fits into a punitive model that is focused on the offence alone and not on the social situation of the child. ${ }^{40}$

Another possibility is that children who are above the MACR are not considered criminally responsible in certain circumstances. In these countries, the doli incapax principle (the principle of discernment) applies. ${ }^{41}$ The doli incapax presumption holds that children under a certain age, but above the formal MACR, are not capable of committing a crime, until proven otherwise. As a consequence, most children will not be prosecuted because they are deemed not to be criminally responsible. ${ }^{42}$ In France, for example, where formally no MACR is laid down in law, children below the age of ten can be found capable of discernment when they have committed an offence, but only protective and educational measures can be imposed in that case (Art. 122-8 Code Pénal). The judge has the discretion to assess and determine whether the child can be held criminally responsi-

37. UN Committee on the Rights of the Child (2019), above n. 31, para. 25; See also N. Lynch, "Human Rights for "Hard Cases": Alternatives to Imprisonment for Serious Offending by Children and Youth', in E. Stanley (ed.), Human Rights and Incarceration (2018) 153.

38. D. Cipriani, Children's Rights and the Minimum Age of Criminal Responsibility: A Global Perspective (2009).

39. I. Weijers and T. Grisso, 'Criminal Responsibility of Adolescents: Youth as Junior Citizenship', in J. Junger-Tas and F. Dünkel (eds.), Reforming Juvenile Justice (2009) 45; European Commission, Summary of Contextual Overviews on Children's Involvement in Criminal Judicial Proceedings in the 28 Member States of the European Union (2014), https://publications.europa.eu/en/publication-detail/-/publication/ 78efc2f4-746e-485c-9c18-9d2509deeedf.

40. R. Arthur, 'Exploring Childhood, Criminal Responsibility and the Evolving Capacities of the Child: The Age of Criminal Responsibility in England and Wales', 67 Northern Ireland Legal Quarterly 269, at 273 (2016)

41. European Commission, above n. 39

42. K. Hollingsworth, 'Responsibility and Rights: Children and Their Parents in the Youth Justice System', 21 International Journal of Law, Policy and the Family 190 (2007); Cipriani, above n. 38; T. Crofts, 'Reforming the Age of Criminal Responsibility', 46 South African Journal of Psychology 436 (2016) ble at any age and from the age of thirteen criminal sanctions can be applied (Art. 2 Ordonnance $\mathrm{n}^{\circ} 45-174$ du 2 février 1945 relative à l'enfance delinquente). ${ }^{43}$

At the other end of the spectrum, most countries have set the age of criminal majority at the age of eighteen. Scotland is a notable exception to this rule, where young people from the age of sixteen are held fully criminally responsible. ${ }^{44}$ Other countries also apply exceptions to this rule, in case of serious crimes, prosecuting minors below the age of eighteen in an adult court (e.g. England and Wales and Ireland from the age of ten) or applying adult sentences (e.g. the Netherlands, France and Belgium from the age of sixteen). In some countries, exceptions are made for young adults between eighteen and twenty-one or twenty-three years of age, who can be dealt with according to the juvenile criminal law and/or receive mitigated sentences (e.g. Germany, Austria, the Netherlands). ${ }^{45}$ Some recent developments in this regard, such as raising the upper age limit for young adults eligible to be dealt with in the juvenile justice system in the Netherlands from twenty-one to twentythree, have been informed by insights from developmental or neuropsychological research. ${ }^{46}$ Such evidence-based developments in shifting age limits can be contrasted with developments in other countries, where the MACR or the age of criminal majority is lowered to apply adult criminal law to juveniles as part of a more repressive approach towards juvenile delinquency. ${ }^{47}$ This highlights the need to address the various arguments underlying age limits, which will be further discussed in the subsequent section.

Finally, some countries have set age limits for the application of certain sentences, most notably, detention. Generally, in Europe, the minimum age for detention is the same as the MACR, ${ }^{48}$ but in Switzerland, for example, children can only be detained from the age of fifteen, although the MACR is ten (Art. 22-25 Jugendstrafgesetz, 9 October 2003). In France, a multi-staged sanctioning system exists: below the age of ten children can be found capable of discernment, but only protective and educational measures can be imposed (Art. 122-8 Code Pénal), children between ten and thirteen

43. Cipriani, above n. 38

44. L. Francoz-Terminal, 'La spécificité de la réponse 1a l'acte de délinquance du mineur en Angleterre et en Écosse', in Y. Favier and F. Ferrand (eds.), La justice des mineurs en Europe. Une question de spécialité? (2011) 91

45. K. Zeijlmans, T. Sipma and A.M. van der Laan, De aparte bejegening van jongvolwassen daders in het (jeugd)strafrecht: Een internationale vergelijking (2019); E.P. Schmidt, S.E. Rap and T. Liefaard, 'Young Adults in the Justice System: The Interplay Between Scientific Insights, Legal Reform and Implementation in Practice in the Netherlands', Youth Justice (online first 6 January 2020).

46. S. Matthews, V. Schiraldi and L. Chester, 'Youth Justice in Europe: Experience of Germany, the Netherlands, and Croatia in Providing Developmentally Appropriate Responses to Emerging Adults in the Criminal Justice System', 1 Justice Evaluation Journal 59 (2018); see for some critical reflections on this development Schmidt, Rap and Liefaard, above n. 45.

47. See for an overview https://archive.crin.org/en/home/what-we-do/ policy/stop-making-children-criminals/states-lowering-age-criminalresponsibility.html (last visited 8 July 2019)

48. FRA (2018), above n. 35. 
years of age can only receive an educational measure or educational sanction (Art. Ordonnance $n^{\circ} 45$ ) and criminal sanctions can be imposed on children from the age of thirteen, with the exception of community service, which can only be imposed from the age of sixteen, when minors are allowed to be engaged with paid labour (Art. 20-5 Ordonnance n ${ }^{\circ} 45$; Art. 122-8 Code Pénal).

\subsubsection{Family Lam and Care Proceedings}

Age limits also apply in the area of family law and child protection, for example, with regard to the legal capacity of children to act in proceedings and the age from which children are involved and heard in judicial proceedings. Kennan and Kilkelly conclude from their review of EU member states that provisions aiming at ensuring access to judicial proceedings for children 'tend to be more rigorous in the areas of family law and placement in care than in other areas of law'. ${ }^{49}$ One explanation for this is that the decisions made by the courts in these case directly concern the life of children, for example, in the case of custody and living arrangements, mandatory supervision or out-of-home placement. Recent research in the Netherlands shows that no explicit purpose of hearing children in family law proceedings is indicated in the Dutch law, but judges indicate that the main goal is to give children the opportunity to tell their story. ${ }^{50}$ Mol concludes from her comparative legal study involving New South Wales, Australia, South Africa, France and the Netherlands that capability requirements of children in family law proceedings 'take on all shapes and sizes'. ${ }^{1}$ The author focusses on the question whether children are provided with a (legal) representative in family law proceedings and on which factors the appointment of a representative depends. In some of these jurisdictions, in order to have a representative appointed children must have capability or should have reached a certain age; for example, in the Netherlands, only children from the age of twelve can have a separate legal representative in care and supervision order proceedings. In other jurisdictions, the appointment of a representative depends on the lack of capability or young age of the child (e.g. New South Wales). In French family law proceedings, equal to the juvenile justice system, the principle of capable de discernement (capable of discernment) applies, and the judge has the discretion to determine whether the child is capable of being heard, for example. In general, children from the age of seven are considered capable to participate in proceedings. ${ }^{52}$ Also, in England and Wales, children have

49. Kennan and Kilkelly (2015), above n. 33, at 5 .

50. M.R. Bruning, D.J.H. Smeets, K.G.A. Bolscher, J.S. Peper and R. de Boer, Kind in proces: van communicatie naar effectieve participatie. Het hoorrecht en de procespositie van minderjarigen in familie- en jeugdzaken (2020), at 185, 238.

51. C. Mol, 'Children's Representation in Family Law Proceedings. A Comparative Evaluation in Light of Article 12 of the United Nations Convention on the Rights of the Child', 27 The International Journal of Children's Rights 66, at 88 (2019).

52. J.-L. Rongé (2008) and D. Attias (2012) in Mol, above n. 51. to prove their understanding to be able to participate and give their views in family law proceedings. ${ }^{53}$

FRA has recently analysed children's right to be heard in adoption, placement (assigning a child to a suitable place to live) and divorce and custody cases in EU member states and concludes that in fewer than half of the member states children are heard without applying any age restrictions or other requirements. ${ }^{54}$ Twelve member states have laid down specific age limits for children to be heard, ranging from ten to fourteen years in divorce and custody and adoption cases and ten to sixteen years in placement in care proceedings. Even within countries different age limits apply in different proceedings, and the child's consent to such decisions is not always necessary. In adoption cases, for example, only twelve member states ask for a child's own consent, three of which do not apply minimum age requirements. ${ }^{55}$ Naturally, in family law and care proceedings, the age of majority is generally set at eighteen. However, as is the case in the field of juvenile justice, calls are made to extend care arrangements past the age of eighteen, to provide young care leavers with the opportunity to receive care and protection until they have reached full independence. For example, in the Netherlands it is possible since 2018 for young people to stay in (statefunded) foster care until the age of twenty-one, and youth care arrangements can be extended until the age of twenty-three. ${ }^{56}$

\subsubsection{Migration Lam}

Age limits are applied in the field of migration law as well. For example, countries apply different age limits with regard to the legal capacity of children to apply for asylum and the age from which children are heard by the immigration authorities. Drywood has observed that within the EU - at least under the first phase of the Common European Asylum System (CEAS) - age thresholds were used to control migration flows by limiting the rights of older children in asylum legislation and family reunification. ${ }^{57}$ Nowadays, in all member states, unaccompanied children can act as a sponsor in the family reunification procedure, except in the United Kingdom, but quotas are still set by countries and procedures can take a very long time. ${ }^{58}$

When children arrive in a country in the company of their parents, the parents usually apply for asylum for themselves and their underage children and children are not allowed to apply for asylum on their own. However,

53. Arthur, above n. 40

54. FRA (2018), above n. 35.

55. Ibid.

56. M.R. Bruning, T. Liefaard, M.M.C. Limbeek and B.T.M. Bahlmann, Verplichte (na)zorg voor kwetsbare jongvolwassenen? Onderzoek naar de juridische mogelijkheden voor (verplichte) hulp aan kwetsbare jongvolwassenen na kinderbescherming (2016).

57. E. Drywood, 'Challenging Concepts of the "Child" in Asylum and Immigration Law: The Example of the EU', 32 Journal of Social Welfare and Family Law 309 (2010).

58. Coram Children's Legal Centre, Migrant Children's Project FACT SHEET: Family Reunion (2017a), https://www.childrenslegalcentre. com/wp-content/uploads/2017/05/Family_reunion_May.2017.final_. pdf. 
in five EU member states, accompanied children have the right to make an application on their own behalf when they are twelve years or older (in the Netherlands; moreover, in this country, they are required to from the age of fifteen), fourteen years (in Bulgaria, Hungary and Romania) or fifteen years (in Greece), respectively. Belgium, Denmark, Portugal and the United Kingdom extend this right to all children, because they have not defined a minimum age limit. ${ }^{59}$

Children who arrive in a country alone can also lack the legal capacity to apply for asylum as a consequence of age limits laid down by countries. In fourteen EU member states, unaccompanied children cannot independently apply for asylum and they therefore need a legal representative until they are $18 .^{60}$ Ten other EU member states have not set any age limit and other countries have set the same age limit as for accompanied children (see the previous paragraph). This means that children below that age depend on a representative to file the asylum application. ${ }^{61}$

With respect to children applying for asylum, different age limits are applied to hearing children in the procedure as well. In ten EU member states specific age limits are laid down for hearing children in asylum cases, ranging from six to eighteen years. In nine other member states, courts decide on an ad hoc basis whether or not to provide children with the opportunity to be heard. ${ }^{62}$ For example, in the United Kingdom, all unaccompanied children from the age of twelve are interviewed by the immigration authorities and children below the age of twelve can be interviewed if they are willing and found to be mature enough. ${ }^{63}$ In the Netherlands, unaccompanied children from the age of six are heard, in a child-friendly interview room and by a specially trained immigration officer. Accompanied children are in principle always heard from the age of fifteen, because they have to file their own asylum application. ${ }^{64}$

From this (limited) overview of age limits as applicable in three different areas of law, it can already be concluded that states vary widely in the application of age

59. FRA (2018), above n. 35; FRA, Mapping Minimum Age Requirements with Respect to the Rights of the Child in the EU. Asylum Applications for Accompanied Children (2017a), https://fra.europa.eu/en/ publication/2017/mapping-minimum-age-requirements/asylumaccompanied

60. FRA, Mapping Minimum Age Requirements Concerning the Rights of the Child in the EU. Asylum Applications for Unaccompanied Children (2017b), http://fra.europa.eu/en/publication/2017/mappingminimum-age-requirements/asylum-unaccompanied.

61. FRA (2018), above n. 35; see also D. Rosani, 'Unaccompanied AsylumSeeking Children as Rights Holders: Theory and Reality in the EU Legal System in the Case of Age Assessment and Applications for International Protection', in P. Rodrigues, M. Klaassen, S. Rap and T. Liefaard (eds.), Safeguarding Children's Rights in Immigration Law (2020) 41.

62. FRA (2018), above n. 35.

63. Coram Children's Legal Centre, Migrant Children's Project FACTSHEET: Claiming Asylum as a Child (2017b), https://www.childrenslegal centre.com/wp-content/uploads/2016/10/Claiming-asylum-as-a-childAugust2017.final_.pdf.

64. Dutch House of Representatives, Vluchtelingenbeleid (2004), at 14 https://zoek.officielebekendmakingen.nl/kst-19637-824.pdf (last visited 8 July 2019). limits and the assignment of legal capacity to children. A plethora of diffuse laws and regulations can be identified, which show how between areas of law different standards are applied. Often, age limits are used to involve or exclude children in different legal systems on different grounds. Sometimes children are excluded categorically to protect them (e.g. in family or care proceedings); sometimes they are included, on the basis of their presumed accountability (e.g. juvenile criminal law) or for information-gathering purposes (e.g. in migration law).

\section{Discussion and Conclusions}

The underlying proposition of the CRC is that children require specific rights and protections that acknowledge their age and (im)maturity and that, at the same time, they should be acknowledged as participants and agents, entitled to be empowered through participatory rights, evolving autonomy and legal capacity to exercise their rights. ${ }^{65}$ Naturally, age limits are inherently tied to a specific view on children: they can be seen as vulnerable and in need of protection (leading to, for example, the establishment of minimum age limits for the exercise of certain rights or not holding them accountable for their behavior in criminal law procedures), while in other cases they are seen as (increasingly) capable and autonomous (for example, in terms of their participation in judicial procedures). This has different implications, particularly, for states parties as the primary duty bearers under international children's rights law. First, this implies a balancing exercise between the protection of children and their empowerment and participation. ${ }^{66}$ Second, this requires a reflection upon the concepts of age, development, maturity, evolving capacities and growing autonomy, which play a pivotal role within the CRC framework. ${ }^{67}$ The CRC aims to resolve the tension between the need to protect and the need to empower children through the notion of evolving capacities. In practice, however, the more fluid notions underlying the CRC are regulated by states parties through the more static concepts of age and age limits.

In this contribution, the central issue revolves around the question, To what extent is the use of (certain) age limits justified under international children's rights law? The reasons for the involvement of children in judicial proceedings vary widely among legal fields and different countries and can be underpinned by scientific evid-

65. The right to be heard can be found in several provisions of the CRC; more generally, participation is provided for in Arts. 13 (freedom of expression), 14 (freedom of thought, conscience and religion) and 15 (freedom of association), and specifically regarding different contexts, in Arts. 9(2) (separation from the parents), 21(a) (adoption), 23(1) (children with disabilities), 31(1) (cultural activities), 37(d) (deprivation of liberty) and 40(2)(b)(iv) (juvenile justice).

66. T. Liefaard, 'Child-Friendly Justice: Protection and Participation of Children in the Justice System', 88 Temple Law Review 905 (2016).

67. The concepts of age, maturity, development and capacities play a role in Arts. 5, 6, 12, 14, 18, 23, 27, 28, 31, 32, 37, 38 and 40 CRC. 
ence, political arguments or ideological preferences. ${ }^{68}$ This also shows the variety of conceptualisations and definitions states and legal fields attach to childhood and the presumed capacities of children. The CRC provides rather open norms, such as 'evolving capacities' and 'due weight', which gives states considerable leeway in how they involve children in judicial procedures. Distinguished children's rights scholars, such as Freeman and Eekelaar, have advocated that limitations to children's autonomy rights should be well substantiated, for example, with due reference to the protection of their unhindered development. ${ }^{69}$ In addition, the CRC Committee has made numerous recommendations on the establishment of certain age limits in attempting to provide guidance to member states and at the same time has advocated for flexibility and the possibility of applying exceptions to the norm, in case that would benefit the child. This has led to a rather inconsistent and scattered image of age limits under the CRC. The diverging views and perspectives of the CRC Committee find their basis in the inconclusive guidance provided by the CRC provisions themselves and, admittedly, do not make it simple for states parties to establish age limits in conformity with the international children's rights framework.

As stated earlier, age limits can sometimes act as a protection for children, for example, from being prosecuted and convicted in the adult criminal justice system, by providing them with mandatory legal support and by providing legal certainty about whether they are granted legal capacity and other entitlements. ${ }^{70}$ Refraining from laying down age limits in law could lead to legal uncertainty for children, because decision makers would then be given the discretion to decide whether children are capable enough to act in a legal procedure. This is one reason why the CRC Committee is not in favour of applying the doli incapax principle in juvenile justice proceedings. ${ }^{71}$ On the other hand, age limits are also arbitrary, restrictive and rigid in the sense that they can exclude children from certain legal proceedings when no exceptions to the age threshold can be or are made in practice. This means that age limits can restrict the participation of children in judicial proceedings and categorically exclude children when they fall below the set age limit. Alternatively, age limits can establish legal obligations for children to participate without decision makers being in the position to make an individualised assessment of the capacities of the child to be heard in the procedure. $^{72}$

68. Hanson, above n. 8, at 68-69. See also A.O. Cohen, R.J. Bonnie, K. Taylor-Thompson and B.J. Casey, 'When Does a Juvenile Become an Adult: Implications for Law and Policy', 88 Temple Law Review 769, at 769 (2016).

69. Eekelaar, above n. 10, at 170-171; Freeman (1992), above n. 10, at 68 .

70. Crofts, above n. 42; Arthur, above n. 40; C. McDiarmid, 'After the Age of Criminal Responsibility: A Defence for Children Who Offend', 67 Northern Ireland Legal Quarterly 327 (2016); Hollingsworth (2007), above n. 42.

71. UN Committee on the Rights of the Child (2019), above n. 31, paras. 26-27.

72. It should be borne in mind that participation in judicial proceedings can also have harmful consequences for children, for example, when they
On the basis of the analysis presented, our tentative conclusion is that states apply age limits not seldomly on the basis of practical, political or ideological arguments. While age limits are often indispensable to provide legal professionals guidance and the child involved legal certainty, they should be scrutinised to establish whether they - and especially the aims underlying them - are in line with international children's rights law, leaving room for the child's autonomy when possible and providing protection when necessary. At this time, an overarching view on the evolving autonomy of the child as rights holder, having legal capacity, is largely lacking. This may partly be the result of the inconclusive guidance provided by the CRC Committee on this point. The dynamic legal position of children, influenced by their development and level of maturity, should be acknowledged and applied more consistently by the CRC Committee, as well as individual states parties, to provide a dynamic and coherent perspective on children's growing autonomy while at the same time safeguarding their legal protections and entitlements. ${ }^{73}$ This should lead to a well-thought through balance between protection and participation of children.

Indeed, this is not a simple task. A positive development that has taken place in this regard - and will hopefully gain force at both the national and international level is the more frequent reference by the CRC Committee to scientific insights on the development of children when recommending certain age limits (e.g. in the justice system). ${ }^{74}$ However, a principled stance by states in how and the extent to which children are seen as being different from adults, with a different legal status and special rights, is needed as well in order to develop a consistent approach towards children, their potential and the role of the law therein. ${ }^{75}$ In general, the arguments and aims underlying certain age limits should be made explicit in order to promote an evaluation of age limits on the basis of the international children's rights framework. Moreover, states should analyse the existing opportunities to secure access to justice, and consequently grant children (effective) remedies, so children can challenge the way they are being treated. This can increase their level of autonomy ${ }^{76}$ and ensure that

are not involved in an appropriate and child-friendly manner. This may lead to traumatic experiences and secondary victimisation. See L. Darmanaki Farahani and G.L. Bradley, 'The Role of Psychosocial Resources in the Adjustment of Migrant Adolescents', 12 Journal of the Pacific Rim Psychology 1 (2018); E. Chase, 'Security and Subjective Wellbeing: The Experiences of Unaccompanied Young People Seeking Asylum in the UK', 35 Sociology of Health and IIIness 858 (2013); J.A. Quas and G.S. Goodman, 'Consequences of Criminal Court Involvement for Child Victims', 18 Psychology, Public Policy, and Law 392 (2012).

73. See also Varadan, above n. 2, at 333

74. See also the positive evaluation of the increased use of developmental research by American lawmakers in E.S. Scott and C. Huntington, 'Conceptualizing Legal Childhood in the Twenty-First Century', Columbia Public Law Research Paper No. 14-633 (2019).

75. Hollingsworth (2013), above n. 9.

76. See also T. Liefaard, 'Access to Justice for Children: Towards a Specific Research and Implementation Agenda', 27 The International Journal of Children's Rights 195 (2019). 
states can be held accountable vis-à-vis children and their rights. 